\title{
Role of DECT in a patient with atypical gout flare
}

\author{
Kosar Hussain (1) , ${ }^{1}$ Sana Shahid, ${ }^{1}$ Winston Chang ${ }^{1,2}$
}

'General Medicine, Goulburn Valley Health, Shepparton, Victoria, Australia ${ }^{2}$ Rheumatology, Goulburn Valley Health, Shepparton, Victoria, Australia

\section{Correspondence to}

Dr Kosar Hussain;

dockohu@gmail.com

Accepted 25 September 2019

\section{DESCRIPTION}

A 37-year-old man presented with a 3-day history of increasing pain in both calves and posterior thighs. The pain was severe, rendering him unable to weight bear. There was no preceding history of trauma. Pain was worst at night and there were no other associated systemic symptoms. He reported similar episodes lasting 2-3 days over the past year. There were no obvious provoking factors. Each episode had been self-limiting, responding to a short course of over-the-counter non-steroidal anti-inflammatory drug (NSAIDs). His medical history was significant for an episode of gout that affected his metatarsophalangeal joints. On examination he was afebrile and there was small left suprapatellar effusion. There was no other joint swelling. There was no obvious rash or tophi. His blood tests revealed a mild neutrophilic leucocytosis of $11.8 \times 10^{3} / \mu \mathrm{L}$ (3.6-9.2), elevated $C$ reactive protein (CRP) at $140 \mathrm{mg} / \mathrm{L}(<5)$, creatine kinase $(\mathrm{CK})$ of $84 \mathrm{u} / \mathrm{L}$ and a urate level of $0.40 \mathrm{mmol} / \mathrm{L}$. Renal function was also normal. Plain knee X-rays were unremarkable. A diagnostic left knee arthrocentesis yielded a dry tap. The main differentials were gout versus other causes of inflammatory arthropathies.

Images of the patient's knees were taken with a dual-source CT scanner which was then processed using a commercial software program ('Gout', syngo.via VB10 software package, Siemens). A dual-energy CT (DECT) scan of the knees demonstrated monosodium urate (MSU) crystal deposition at the menisci, collateral ligaments and prepatellar regions (figures 1 and 2). Our patient was commenced on a course of oral glucocorticoids and colchicine with a good clinical response. He was followed up in the outpatient clinics after

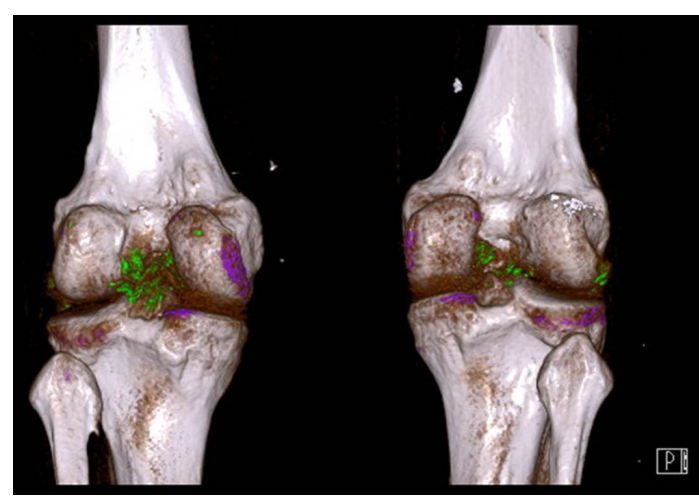

Figure 1 Two-material decomposition multiplanar reformatted images of both knees were obtained. Volume-rendered images of anterior view (A) and posterior view (B) display numerous urate tophi (green) seen in the menisci, collateral ligaments, prepatellar regions.

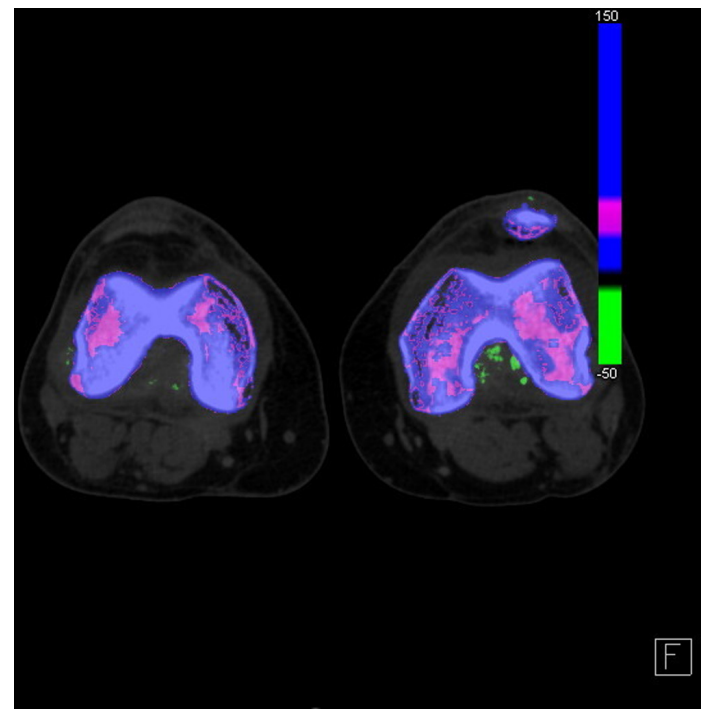

Figure 2 Two-material decomposition axial multiplanar reformatted colour-coded images of both knees show mild degree of monosodium urate deposition (green) confirming presence of gout.

1 month. His symptoms had completely resolved. He was then initiated on allopurinol.

Visualising negatively birefringent MSU crystals in synovial aspirates remain the gold standard tests for diagnosis of gout. However, joint aspiration may not always be obtainable either for technical reasons or lack of patient consent for the procedure.

DECT has emerged as a highly specific and non-invasive method for detection of MSU deposition in the joints. It is now recognised in the latest guidelines by American College of Rheumatology/ European League Against Rheumatism guidelines, where it is included as a diagnostic modality in the gout classification criteria. ${ }^{1}$ DECT scanners are equipped with two X-ray tubes which allow simultaneous acquisition at two different energy levels. It is thus, superior to the present single-source CT because of its enhanced ability to characterise the chemical composition of materials. ${ }^{2}$ DECT scans have a sensitivity and specificity of approximately

Learning points

- Sometimes an acute gout flare is difficult to clinically differentiate from other causes of inflammatory arthropathy and require a more thorough diagnostic work-up.

- Dual-energy CT can be used as a diagnostic tool for selective patients with acute gout flare, especially with atypical presentations where arthrocentesis cannot be performed. 
$75 \%$ and $93 \%$, respectively for detecting gouty arthropathy. ${ }^{3}$ It not only aids in establishing the diagnosis of gout, but also helps in quantifying the severity and anatomic distribution of the urate crystals.

It is important to be aware that DECT is subject to limitations and false positive results may be caused by artefacts. Therefore, the results must be interpreted in the context of clinical findings. DECT is also associated with increased radiation exposure in comparison with other imaging modalities and this factor limits its recurrent use. ${ }^{4}$

In this case, we present a case of gout with atypical presentation requiring confirmation of diagnosis without a joint aspirate. This patient likely has radiation of pain from the knee of tendinopathy from gout. We aim to highlight the utility of a DECT scan in diagnosing this patient.

Contributors $\mathrm{KH}$ has written the manuscript. SS has taken clinical history from patient. WC has reviewed the manuscript.
Funding The authors have not declared a specific grant for this research from any funding agency in the public, commercial or not-for-profit sectors.

Competing interests None declared.

Patient consent for publication Obtained.

Provenance and peer review Not commissioned; externally peer reviewed.

\section{ORCID iD}

Kosar Hussain http://orcid.org/0000-0002-0437-5788

\section{REFERENCES}

1 Neogi T, Jansen TLTA, Dalbeth N, et al. 2015 gout classification criteria: an American College of Rheumatology/European League against rheumatism collaborative initiative. Arthritis Rheumatol 2015:67:2557-68.

2 Nicolaou S, Liang T, Murphy DT, et al. Dual-Energy CT: a promising new technique for assessment of the musculoskeletal system. AJR Am J Roentgenol 2012;199(5 Suppl):S78-S86.

$3 \mathrm{Hu} \mathrm{H}-J$, Liao M-Y, Xu L-Y. Clinical utility of dual-energy CT for gout diagnosis. Clin Imaging 2015;39:880-5.

4 Davies J, Riede P, van Langevelde K, et al. Recent developments in advanced imaging in gout. Ther Adv Musculoskelet Dis 2019;11:1759720X1984442. 1759720X19844429. Published 2019 Apr $16 .$.

Copyright 2019 BMJ Publishing Group. All rights reserved. For permission to reuse any of this content visit

https://www.bmj.com/company/products-services/rights-and-licensing/permissions/

BMJ Case Report Fellows may re-use this article for personal use and teaching without any further permission.

Become a Fellow of BMJ Case Reports today and you can:

- Submit as many cases as you like

- Enjoy fast sympathetic peer review and rapid publication of accepted articles

- Access all the published articles

Re-use any of the published material for personal use and teaching without further permission

\section{Customer Service}

If you have any further queries about your subscription, please contact our customer services team on +44 (0) 2071111105 or via email at support@bmj.com.

Visit casereports.bmj.com for more articles like this and to become a Fellow 